\title{
HUBUNGAN ANTARA KETERAMPILAN PENJUALAN DAN KINERJA TENAGA PENJUAL DI PERUSAHAAN CAT INDONESIA
}

\section{THE RELATIONSHIP BETWEEN SALES SKILLS AND SALES PERFORMANCE AT A PAINT COMPANY IN INDONESIA}

\author{
Aria Eddy Kertocahyono1), Haryanto Ginting2), Julius Kurata ${ }^{3)}$, Risnawati \\ Dermauli ${ }^{4}$, Sony Chandra Sihaloho ${ }^{\left.5^{*}\right)}$ \\ 1,2,3,4,5) Universitas Prasetiya Mulya, Jl. RA Kartini Cilandak Jakarta Selatan, DKI Jakarta, 12430 \\ *) Corresponding Author
}

\begin{tabular}{|c|c|}
\hline ARTICLE INFORMATION & A B S T R A C T \\
\hline & The phenomenon of the existence of a successful salesperson and does \\
\hline $\begin{array}{l}\text { Received: October 14, } 20 \\
\text { Revised: October 22, } 20 \\
\text { Accepted: November 18, } 20\end{array}$ & $\begin{array}{l}\text { not indicate that the variables affect the salesperson's performance. The } \\
\text { understanding is beneficial for the company to provide training focus. The } \\
\text { purpose of this study is to test the influence of sales skills dimensions } \\
\text { (interpersonal skill, salesmanship skill, marketing skill, company's product } \\
\text { knowledge and competitors' product knowledge) on salesperson } \\
\text { performance in a domestic paint company which has the potential to }\end{array}$ \\
\hline $\begin{array}{l}\text { Keywords: } \\
\text { Salesmanship skill } \\
\text { Sales force performance } \\
\text { Paint manufacture company }\end{array}$ & $\begin{array}{l}57 \text { Supervisors with samples amounting to } 268 \text { salespersons form } 348 \\
\text { population. The method is linear regression analysis through SPSS } \\
\text { Statistik } 26 \text { th edition software. This analysis was conducted to test the } \\
\text { influence of sales skills dimensions on salesperson performance. Based on } \\
\text { the questionnaire, it is evident that salesmanship and interpersonal skills } \\
\text { have a significant influence on salesperson performance. On the contrary, } \\
\text { the remaining three dimensions were found to have no influence on } \\
\text { salesperson performance. }\end{array}$ \\
\hline
\end{tabular}

Kata kunci:

Keterampilan penjualan

Kinerja tenaga penjual

Perusahaan cat

\begin{abstract}
A B S T R A K
Fenomena adanya tenaga penjual yang sukses dan yang gagal menunjukkan bahwa terdapat variabel yang memengaruhi kinerja tenaga penjual. Pemahaman ini bermanfaat bagi perusahaan untuk memberikan fokus pelatihan. Penelitian ini ditujukan untuk menguji pengaruh dimensi keterampilan penjualan yakni: keterampilan interpersonal, keterampilan keahlian menjual, keterampilan pemasaran, kemampuan pengetahuan produk perusahaan dan kemampuan pengetahuan produk pesaing terhadap kinerja tenaga penjual di sebuah perusahaan cat nasional yang memiliki potensi untuk memengaruhi kinerja tenaga penjual. Kuesioner didistribusikan kepada 57 Supervisor dengan sampel sebanyak 268 orang dari populasi sejumlah 348 orang. Metode analisis regresi linier menggunakan perangkat lunak SPSS Statistik edisi 26 , analisis ini untuk menguji atas pengaruh dimensi keterampilan terhadap kinerja dari tenaga penjual. Berdasarkan pengumpulan kuesioner terlihat bahwa keterampilan dalam penjualan dan keterampilan interpersonal secara signifikan memengaruhi kinerja tenaga penjual. Sementara itu, ketiga dimensi yang lain tidak berpengaruh terhadap kinerja tenaga penjual.
\end{abstract}

${ }^{*}$ Corresponding Author

This is an open access article under the $\underline{\mathrm{CC}-\mathrm{BY}}$ license.

Name

E-mail: sony.sihaloho@student.pmbs.ac.id

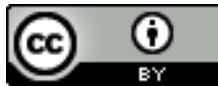




\section{PENDAHULUAN}

\subsection{Umum}

Industri cat merupakan salah satu sektor dari industri kimia. Secara makro di negara Nyiur Melambai Indonesia ini, industri cat masih dapat dinyatakan dalam situasi dan merupakan pasar yang menjanjikan dan memiliki potensi meningkat secara stabil. Pertumbuhan kelas menengah serta jumlah konsumen industri seperti pengembang properti \& real estate, pembuat mebel, industri otomotif, kelautan serta sektor elektronik merupakan variabel-variabel yang mendukung kekuatan industri cat di Indonesia. Industri-industri tersebut membutuhkan konsumsi cat dalam jumlah besar.

Sektor properti adalah pendorong pertumbuhan utama industri cat di Indonesia. Tingginya permintaan rumah-rumah baru juga didorong oleh pemerintah Indonesia yang menjadikan pembangunan infrastruktur sebagai salah satu prioritas utama. Pada tahun 2014, pemerintah Indonesia meluncurkan program satu juta rumah. Di bawah inisiatif ini, pemerintah bertekad untuk membangun satu juta unit rumah setiap tahun hingga berakhir pada 2019. Indonesia juga mempunyai suatu tradisi yang banyak dilakukan terutama di daerah-daerah yaitu tradisi mengecat rumah menjelang hari raya keagamaan seperti Idul Fitri dan Natal. Tradisi ini membuat permintaan produk cat meningkat pada momenmomen tersebut. Selain itu, dalam beberapa tahun terakhir terdapat permintaan yang tumbuh secara signifikan di sektor kelautan dan mebel. Sektor Mebel menawarkan potensi besar karena Indonesia adalah salah satu dari tiga produsen mebel teratas di ASEAN bersama dengan Vietnam dan Malaysia [1].

Tingkat konsumsi cat domestik Indonesia di tahun 2010 berada di angka 772.454 ton dan di tahun 2014 tingkat konsumsi melonjak di angka 877.459 ton dengan nilai kapitalisasi pasar mencapai 15 triliun rupiah. Demikian juga, ekspor cat Indonesia juga naik dari 21.742 ton di 2010 menjadi 29.068 ton di 2015. Sementara itu, impor juga naik di tahun 2013 dari 45.927 ton hingga 65.392 ton di tahun 2014. Segmen pasar cat dekoratif memberikan kontribusi sebesar 50\% - 60\% dari total pasar penjualan cat di Indonesia, diikuti segmen pasar cat industri dan segmen pasar cat otomotif berada di urutan berikutnya [1].

Industri cat adalah salah satu dari sedikit sektor bisnis di Indonesia yang melibatkan pelaku bisnis domestik yang kuat dengan merek lokal yang mendominasi pangsa pasar cat $75 \%$ hingga $80 \%$. Indonesia adalah pasar cat terbesar di Asia Tenggara karena memiliki populasi yang besar (261 juta jiwa), tingkat urbanisasi yang tinggi (57 persen), industri otomotif yang dinamis dan peningkatan pendapatan masyarakat kelas menengah yang tinggi. Besarnya pasar dan banyaknya produsen cat membuat kompetisi antar produsen cat menjadi sangat tinggi.

Penelitian ini dilakukan pada sebuah perusahaan cat Indonesia yang berkantor pusat di Tangerang, Indonesia. Cat merupakan salah satu produk industri di mana dalam penjualannya peran dari tenaga penjual lebih besar dibandingkan jenis promosi lainnya. Penelitian ini dilakukan pada sebuah perusahaan cat Indonesia yang berkantor pusat di Tangerang serta memiliki 38 cabang di Indonesia. Area pemasaran dibagi menjadi 7 region yaitu: Sumatra dengan kontribusi penjualan $15 \%$, Jakarta 28\%, Jawa Barat $11 \%$, Jawa Tengah 15\%, Jawa Timur 17\%, Bali Papua $8 \%$ dan Kalimantan Sulawesi 6\%. Perusahaan cat ini memiliki 3 segmen pasar yaitu retail, industri dan proyek. Penelitian ini hanya meneliti segmen pasar retail.

Di segmen pasar retail, cat didistribusikan ke tokotoko cat dan toko-toko bahan bangunan secara langsung oleh pabrik cat atau melalui saluran distribusi distributor, sub distributor dan agenagen. Bagian yang melakukan penjualan dan distribusi ke toko-toko tersebut disebut sebagai tenaga penjual, sedangkan atasan dari para tenaga penjual biasanya dikenal dengan nama Sales Supervisor.

Kondisi persaingan yang tinggi telah menciptakan tekanan besar bagi perusahaan untuk lebih fokus dalam melebarkan pangsa pasar terutama dalam hal penjualan mengingat penjualan produk atau jasa merupakan komponen terpenting dalam pengelolaan dan pengembangan bisnis. Untuk itu tim penjualan harus semakin meningkatkan kreatifitas dan kinerja untuk dapat memberikan kontribusi di angka pendapatan yang tentunya menjadi sarana pendukung seluruh aktivitas bisnis perusahaan. Tenaga penjual merupakan ujung tombak perusahaan karena menjadi wakil perusahaan untuk memperkenalkan produk perusahaan kepada pelanggan, berinteraksi dengan mereka, melakukan transaksi dan melayani kebutuhan mereka. Dengan tujuan utama yaitu meningkatkan pangsa pasar dengan mengutamakan apa yang dibutuhkan oleh pelanggan, manajemen termotivasi untuk semakin mendalami apa yang memengaruhi faktor dari kinerja tenaga penjual. Atas 
pertimbangan tersebut, maka manajemen menggunakan variable kinerja penjualan dalam pengukuran kinerja tenaga penjual [2].

Terdapat beberapa variabel yang berpengaruh terhadap kinerja tenaga penjual. Tenaga penjual dengan keterampilan penjualan yang tinggi memberikan kontribusi yang signifikan dalam pencapaian kinerja yang bersangkutan dalam mencapai target. Salah satu faktor utama yang memengaruhi pencapaian target tenaga penjual adalah keterampilan penjualan tenaga penjual [3]; [4]. Melalui [5] diketahui bahwa tingginya kompetisi lingkungan bisnis memaksa divisi penjualan untuk selalu mencari tenaga penjual yang memiliki keahlian dan memiliki keterampilan tinggi mencapai target penjualan. Seorang tenaga penjual yang memiliki kehandalan menunjukkan capaian pendapatan yang optimum dari pelanggannya dan memiliki kemampuan yang sistematis untuk dapat memproses calon pasar maupun pelanggan baru sehingga pada akhirnya memberikan kontribusi untuk perusahaan bertumbuh secara lebih cepat jika dibandingkan dengan perusahaan pesaing lainnya. Dengan mengerti bahwa tenaga penjual memiliki peranan penting dalam memberikan kontribusi secara positif bagi pertumbuhan penjualan yang terus menerus, maka beranggotakan tenaga penjualan yang sangat terampil menjadi hal yang signifikan dan kritis [4]; [5]; [6]. Hal tersebut juga didukung dengan banyaknya peneliti yang telah menggarisbawahi peran penting tingkat keterampilan tenaga penjual terhadap kinerja tenaga penjual [3]; [7].

Penelitian [8] meneliti keterkaitan antara keterampilan penjualan dan kinerja tenaga penjual di perusahaan telekomunikasi terbesar di Malaysia, yang menunjukkan dimensi keterampilan penjualan yang memiliki hubungan positif signifikan dengan kinerja tenaga penjual hanya keterampilan interpersonal. Penelitian dari [9] yang meneliti tenaga penjual di perusahaan mobil di Amerika Serikat bagian tenggara, menunjukkan hubungan positif yang signifikan antara pengetahuan produk perusahaan dan pengetahuan produk pesaing terhadap kinerja tenaga penjual. Hasil penelitian ini penting bagi perusahaan untuk menentukan strategi pengembangan tenaga penjual. Perusahaan akan memberikan fokus dan biaya lebih besar ke pelatihan-pelatihan peningkatan dimensi keterampilan penjualan yang berpengaruh signifikan terhadap kinerja penjualan.

Berdasarkan hasil dari penelitian yang dilakukan di sektor industri otomotif dan telekomunikasi, maka penelitian ini ingin mengetahui bagaimana hubungan antara masing-masing dimensi keterampilan penjualan dan kinerja tenaga penjual. Dua penelitian sebelumnya yang dijadikan referensi dilakukan di perusahaan mobil dan perusahaan telekomunikasi. Pada penelitian tersebut tenaga penjual menjual produk perusahaan langsung ke pemakai akhir. Pada penelitian ini tenaga penjual yang diteliti berasal dari perusahaan cat. Perusahaan mobil, telekomunikasi dan cat sama-sama menghasilkan produk industri. Berbeda dengan dua penelitian sebelumnya, pada penelitian ini tenaga penjual tidak menjual produk langsung ke pemakai akhir tetapi menjual cat kepada toko-toko yang merupakan salah satu bagian dari saluran distribusi.. Dengan adanya persamaan dan perbedaan tersebut diharapkan penelitian ini dapat lebih memahami pengaruh dimensi keterampilan penjualan yaitu: keterampilan interpersonal, keterampilan keahlian menjual, keterampilan pemasaran, kemampuan pengetahuan produk perusahaan dan kemampuan pengetahuan produk pesaing terhadap kinerja tenaga penjual di sebuah perusahaan cat.

\subsection{Landasan Teori}

Penelitian ini ditujukan untuk menguji pengaruh variabel keterampilan penjualan yang terdiri dari 5 dimensi yaitu: keterampilan interpersonal, keterampilan keahlian menjual, keterampilan pemasaran, kemampuan pengetahuan produk perusahaan dan kemampuan pengetahuan produk pesaing terhadap kinerja tenaga penjual di sebuah perusahaan cat nasional.

Variabel adalah konsep yang memiliki variasi nilai. Nilai diartikan memiliki dan menjadi pembeda dengan yang lain jika konsep tersebut dikaitkan dengan yang lain. Ada beberapa jenis variabel yaitu: variabel bebas, variabel terikat, variabel moderator, variabel perancu, variabel kendali dan variable rambang. Variabel bebas adalah variabel yang nilainya mempengaruhi variabel lainnya, yaitu variabel terikat. Variabel terikat adalah variabel yang nilainya tergantung dari nilai variabel lainnya, yaitu variabel bebas. Variabel moderator adalah variabel yang juga mempengaruhi variabel terikat tapi dalam penelitian pengaruhnya tidak diutamakan. Variabel perancu adalah variabel yang berhubungan dengan varaibel bebas dan variabel terikat tetapi bukan variabel antara. Variabel kendali adalah variabel yang juga mempengaruhi variabel terikat tetapi dalam penelitian keberadaanya dijadikan netral. Variabel rambang 
adalah varaibel yang juga ikut mempengaruhi variabel terikat namun pengaruhnya tidak begitu berarti sehingga keberadaan variabel ini dalam penelitian diabaikan.

Dimensi adalah sejumlah komponen dalam variabel yang yang satu sama lain saling terkait dan menjadi bagian dari satu kesatuan utuh dari suatu variabel. Dalam penelitian sebelumnya [3] ditemukan bahwa terdapat beberapa variabel yang menentukan kinerja tenaga penjual yaitu bakat, keterampilan penjualan, pemahaman peran, motivasi, faktor kepribadian dan faktor organisasi/ lingkungan. Dalam penelitian ini hanya meneliti pengaruh dari variable ketrampilan penjualan.

Di studi lain, [7] keterampilan penjualan dibagi ke dalam tiga dimensi yaitu keterampilan interpersonal, keterampilan keahlian menjual dan keterampilan teknis. Selanjutnya, [10] memperkenalkan keterampilan pemasaran sebagai dimensi lain keterampilan penjualan yang mungkin berpengaruh terhadap kinerja tenaga penjual. Dalam penelitian ini keterampilan teknis dibagi menjadi dua yaitu pengetahuan produk perusahaan dan pengetahuan produk pesaing.

\subsubsection{Keterampilan Penjualan}

Penelitian ini akan melanjutkan penelitian dari [11] yang menguji pengaruh keterampilan penjualan terhadap kinerja tenaga penjual di sebuah perusahaan telekomunikasi Malaysia. Secara spesifik, penelitian ini akan mengolah data atas pengaruh empat dimensi keterampilan penjualan terhadap kinerja tenaga penjual. Empat dimensi keterampilan penjualan adalah keterampilan interpersonal, keterampilan keahlian menjual, keterampilan teknis dan keterampilan pemasaran diambil dari [12] dikutip dalam [4] dan dimensi keterampilan pemasaran diadopsi dari [10]. Dalam penelitian ini dimensi keterampilan teknis dibagi menjadi 2 yaitu pengetahuan produk perusahaan dan pengetahuan produk pesaing. Dimensi pengetahuan produk tersebut merupakan hasil dari [9] yang meneliti pengaruh kemampuan pengetahuan produk perusahaan dan pengetahuan produk pesaing tenaga penjual terhadap kinerja tenaga penjual.

\subsubsection{Keterampilan Interpersonal dan Kinerja Penjual}

Keterampilan interpersonal merupakan keterampilan seseorang dalam berkomunikasi dan berinteraksi dengan orang lain untuk mencapai pengaruh dan hasil tertentu. Keterampilan interpersonal mencerminkan kemampuan tenaga penjual dalam membentuk dan mengembangkan hubungan dengan pelanggan mereka untuk menciptakan keuntungan dan hubungan produktif antara kedua belah pihak. Keterampilan interpersonal yang dimiliki seorang tenaga penjual sangat bermanfaat dalam interaksi dengan pelanggan. Pelanggan akan merasa cukup nyaman berhubungan dengannya sehingga mau membeli apa saja yang dijual tenaga penjual. Tenaga penjual dengan keterampilan interpersonal yang tinggi dapat membuat pelanggan membeli produk yang sebenarnya tidak dibutuhkannya. Keterampilan penjualan interpersonal membangun hubungan jangka panjang dengan pelanggan yang pada akhirnya meningkatkan keuntungan perusahaan.

Menurut [7] ukuran kemampuan interpersonal adalah keterampilan mendengarkan, empati, optimisme dan keterampilan mengamati. Ukuran ini telah diamati dan diuji empiris secara terpisah untuk membuktikan bahwa keterampilan interpersonal memengaruhi kinerja tenaga penjual. [13], [14], [15] menemukan bahwa keterampilan mendengarkan yang efektif adalah keterampilan komunikasi yang berharga bagi kesuksesan tenaga penjualan. Hasil penelitian [11] menyatakan bahwa keterampilan interpersonal berpengaruh positif terhadap kinerja tenaga penjual. Singkatnya, studi empiris sebelumnya menunjukkan hubungan positif antara keterampilan interpersonal pada kinerja tenaga penjual. Melalui penelitian ini kami mengharapkan hubungan yang sama antara keterampilan interpersonal dan kinerja tenaga penjual, sehingga hipotesis pertama:

H1: Ada hubungan positif yang signifikan antara keterampilan interpersonal dan kinerja tenaga penjual.

\subsubsection{Keterampilan Keahlian Menjual dan Kinerja Tenaga Penjual}

Keterampilan keahlian menjual secara garis besar dapat didefinisikan ke dalam lima sub kategori yaitu: kemampuan beradaptasi, penjualan konsultatif, negosiasi, keterampilan bertanya, keterampilan membaca isyarat dan keterampilan komunikasi. Penjualan adaptif merupakan kemampuan dan keahlian tenaga penjual untuk dapat beradaptasi dan mengelola perilaku penjualannya ketika bertemu dan berhubungan 
dengan pelanggan [16]. [17] meneliti bahwa terdapat korelasi positif antara penjualan adaptif dan kinerja tenaga penjual dan efektivitas divisi penjualan. [18] juga menyampaikan bahwa terdapat hubungan positif antara penjualan adaptif dan kinerja penjualan. Proses penting lainnya dalam penjualan adalah negosiasi [6]; [19]. [18] dan [20] menyatakan bahwa keterampilan negosiasi yang dimiliki oleh tenaga penjual berkontribusi terhadap kesuksesan tenaga penjual. Pengaruh kecakapan tenaga penjual lainnya dalam menghasilkan penjualan adalah gaya komunikasi [21]; [22]; [23]; [6]. [24] menyatakan bahwa tenaga penjual yang berhasil adalah tenaga penjual yang dapat mencocokkan gaya komunikasi mereka secara jitu ketika berinteraksi dengan masing-masing tipe pelanggan. Selain itu, perilaku non-verbal seseorang dapat memengaruhi perilaku orang lain [25]. Unsur penting lainnya dari penjualan yang sukses adalah kemampuan tenaga penjual dalam hal berkomunikasi secara nonverbal telah muncul sebagai komponen penting penjualan yang sukses [26]; [6]; [21]; [22]. [23] menyatakan empat ekspresi simbolik nonverbal seperti kualitas suara, vokalisasi nonverbal, gerakan tubuh dan jarak spasial dapat memengaruhi peluang berhasilnya penjualan. Hasil penelitian yang berbeda ditunjukkan oleh [11] yang menyatakan tidak ada hubungan posistif signifikan antara keterampilan keahlian menjual dan kinerja tenaga penjual. Artinya tingkat keahlian menjual yang tinggi tidak berkorelasi dengan kinerja tinggi tenaga penjual. Sementara beberapa studi sebelumnya menunjukkan hubungan positif antara keterampilan keahlian menjual dan kinerja tenaga penjual. Mempertimbangkan hasil-hasil penelitian sebelumnya maka hipotesis kedua adalah:

H2 : Ada hubungan positif yang signifikan antara keterampilan keahlian menjual dan kinerja tenaga penjual.

\subsubsection{Keterampilan Pemasaran dan Kinerja Tenaga Penjual}

Keterampilan pemasaran mengacu pada pemahaman pasar dari industri perusahaan seperti kebutuhan pelanggan, informasi persaingan dan tren industri. Keterampilan pemasaran mengacu pada tingkat pemahaman yang dimiliki tenaga penjual tentang bisnis di mana mereka beroperasi [27]; [6]. [10] mengatakan bahwa keterampilan pemasaran memang memengaruhi kinerja tenaga penjual. Sedangkan [28] mengatakan bahwa ada dua variabel lain yang berpengaruh signifikan terhadap kinerja tenaga penjual yaitu kemampuan strategis dan intrapreneurship. Mempertimbangkan hasil-hasil penelitian sebelumnya maka hipotesis yang berhubungan dengan kinerja tenaga penjual adalah:

H3 : Ada hubungan positif yang signifikan antara keterampilan pemasaran dan kinerja tenaga penjual.

\subsubsection{Pengetahuan Produk dan Kinerja Tanaga Penjual}

Pengetahuan produk adalah kemampuan tenaga penjual dalam menjelaskan desain, spesifikasi, cara aplikasi serta keunggulan produk dan layanan kepada pelanggan. Pengetahuan yang harus dimiliki oleh tenaga penjual diantaranya adalah pemahaman tentang pasar dan tren pasar industri perusahaan, pengetahuan tentang lini produk pesaing, kebijakan penjualan pesaing dan pemahaman operasional pelanggan [29], sebagaimana dinyatakan oleh [30]; [6].

Konsep pengetahuan produk dalam penelitian ini dibagi menjadi dua yaitu pengetahuan produk perusahaan dan pengetahuan produk pesaing. Konsep ini sejalan dengan konsep yang mengatakan bahwa pengetahuan sebagai penjual dan pesaing merupakan aspek yang penting dari pengetahuan produk [31]; [32]. Pengetahuan produk perusahaan menunjukkan kedalaman pengetahuan dan pengetahuan produk pesaing menunjukkan luasnya pengetahuan tenaga penjual. Pengetahuan produk perusahaan dibangun secara internal sedangkan pengetahuan produk pesaing diperoleh melalui proses di lapangan.

Peningkatan pengetahuan produk perusahaan merupakan proses pengembangan internal berkelanjutan berdasarkan produk perusahaan sendiri dan produk. Pengetahuan produk yang tinggi akan sangat bermanfaat dalam menyampaikan nilai produk untuk memenuhi ekspektasi konsumen. Pengetahuan tentang berbagai produk dan merek memungkinkan tenaga penjualan untuk mengomunikasikan manfaat dan nilai merek [33]. Penelitian ini membuktikan jika tingginya kemampuan pengetahuan produk tenaga penjual akan memberikan kepercayaan diri dan kecakapan untuk mengatasi keberatan pelanggan dan akhirnya mampu menghasilkan penjualan.

Sebaliknya, pengetahuan produk pesaing yang dapat didefinisikan sebagai pengetahuan tentang 
informasi penawaran pesaing harus didapatkan dari sumber eksternal dan mencakup dimensi horizontal, luasnya pengetahuan serta pengetahuan produk eksternal. Semakin ketat kompetisi di pasar maka pengetahuan produk pesaing akan semakin diperlukan. Namun di dalam literatur, jenis pengetahuan ini sering dimasukkan dalam konsep yang lebih luas tentang pengetahuan pasar [34]. Sementara dari perspektif pelanggan, selain mengetahui bahwa mereka mendapatkan penawaran terbaik dari perusahaan, pelanggan juga mengharapkan jaminan bahwa penawaran tersebut merupakan yang terbaik di pasar. Jaminan ini hanya dapat diberikan jika tenaga penjual memiliki pengetahuan tentang produk pesaing. Pengetahuan produk pesaing memungkinkan tenaga penjual untuk fokus pada fitur yang paling unggul dari produk mereka yang membedakan dengan produk pesaing. Misalnya fitur atau harga, sehingga dengan menyesuaikan kebutuhan pelanggan akan didapatkan respon yang menguntungkan [33].

Hubungan yang menunjukkan kemampuan pengetahuan teknis yang unggul menghasilkan kinerja tenaga penjual yang lebih tinggi telah dibuktikan secara empiris [17]; [19]; [30]. [35] dan [22] menemukan bahwa kemampuan pengetahuan produk tenaga penjual adalah penting. Melengkapi penelitian sebelumnya, [9] menemukan bahwa pengetahuan produk perusahaan dan pengetahuan produk pesaing masing-masing memiliki hubungan positif terhadap kinerja tenaga penjual.

Dalam penelitian ini hipotesis yang berhubungan dengan kinerja tenaga penjual adalah:

H4 : Ada hubungan positif yang signifikan antara pengetahuan produk perusahaan dan kinerja tenaga penjual.

H5 : Ada hubungan positif yang signifikan antara pengetahuan produk pesaing dan kinerja tenaga penjual.

Secara keseluruhan, penelitian ini menelaah korelasi antara dimensi keterampilan penjualan (keterampilan interpersonal, keterampilan keahlian menjual, keterampilan pemasaran, pengetahuan produk perusahaan dan pengetahuan produk pesaing) terhadap kinerja tenaga penjual. Hubungan antar variabel ditunjukkan pada Gambar 1.

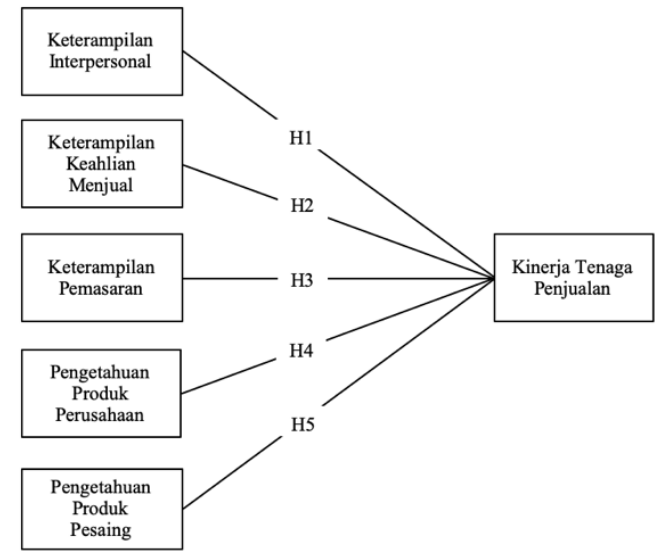

Gambar 1. Kerangka teori penelitian

\section{METODE PENELITIAN}

\subsection{Sampel, Populasi dan Pengumpulan Data}

Subjek penelitian ini adalah tenaga penjual salah satu perusahaan cat di Indonesia. Metode sampling yang digunakan adalah probability sampling, [36] menunjukkan bahwa kekuatan uji statistik meningkat dengan jumlah subjek dalam sampel. Jadi dalam penelitian ini terdiri dari 57 responden dengan posisi Sales Supervisor yang memimpin dan mengawasi minimal satu tenaga penjual. Sales Supervisor dalam kegatan operasional harian berinteraksi langsung dengan para tenaga penjual. Mereka yang paling mengetahui kemampuan ketrampilan penjualan dan kinerja penjualan dari masing-masing tenaga penjual. Populasi tenaga penjual yang akan dinilai berjumlah 348 orang. Para responden diinformasikan bahwa partisipasi bersifat sukarela dan tidak wajib, sehingga diperoleh 57 responden seluruhnya mengembalikan kuesioner yang telah diisi untuk 268 tenaga penjual.

Metode pengumpulan data yang digunakan dalam penelitian ini adalah pengisian kuesioner menggunakan media Google Form yang dikirimkan secara online kepada 57 responden yang memberikan penilaian terhadap 348 tenaga penjual. Responden diberi waktu selama 3 minggu mulai dari tanggal 13 Maret 2020 hingga 2 April 2020 untuk menyelesaikan kuesioner. Penelitian ini mengadopsi pendekatan evaluasi penilaian atasan kepada anak buah (tenaga penjual) di bawah pengawasannya. Hal ini dilakukan karena Sales Supervisor merupakan pihak yang paling mengetahui kemampuan tenaga penjual pada variable-varabel penelitian yang akan dinilai. Sales Supervisor juga merupakan pihak yang paling mengetahui kinerja penjualan dari tenaga penjual. Kuesioner survei 
dibagi menjadi 3 bagian seperti yang ditunjukkan dalam tabel 1 , yang mencakup keterampilan penjualan yaitu keterampilan interpersonal, keterampilan keahlian menjual, keterampilan pemasaran, pengetahuan produk perusahaan, pengetahuan produk pesaing; bagian kedua adalah kinerja tenaga penjual; dan bagian ketiga adalah informasi demografis responden dan tenaga penjual.

\subsection{Pengukuran}

Kuesioner yang digunakan untuk mengukur keterampilan interpersonal, keterampilan keahlian menjual, pengetahuan produk perusahaan dan pengetahuan produk pesaing diadopsi dari [7]. Sementara kuesioner yang digunakan untuk mengukur keterampilan pemasaran diadopsi dari [10], kuesioner kinerja tenaga penjual diadopsi dari [29]. Pada bagian A, responden diminta untuk memberikan penilaian terhadap keterampilan tenaga penjual dari sisi keterampilan interpersonal, keterampilan keahlian menjual, keterampilan pemasaran, pengetahuan produk perusahaan dan pengetahuan produk pesaing. Tingkat penilaian yang diberikan sebanyak 7 poin skala, dimulai dari skala 1 (sangat tidak terampil) hingga skala 7 (sangat terampil). Bagian B, responden memberikan persetujuan atau ketidaksetujuan mereka dengan beberapa pernyataan dengan skala mulai dari 1 (sangat tidak setuju) hingga 7 (sangat setuju).

Tabel 1. Enam variabel

\begin{tabular}{|c|c|c|}
\hline No & Uraian & Referensi \\
\hline I & Keterampilan Interpesonal & \\
\hline 1 & Kemampuan yang bersangkutan untuk mengekspresikan bahasa tubuh & [7] \\
\hline 2 & Kemampuan yang bersangkutan dalam berbicara secara umum & \\
\hline 3 & $\begin{array}{l}\text { Kesadaran dan kemampuan yang bersangkutan memahami komunikasi non- } \\
\text { verbal yang disampaikan orang lain }\end{array}$ & \\
\hline 4 & $\begin{array}{l}\text { Kemampuan yang bersangkutan untuk mengendalikan dan mengatur tampilan } \\
\text { emosi secara non-verbal }\end{array}$ & \\
\hline 5 & Kemampuan yang bersangkutan untuk memengaruhi orang lain & \\
\hline II & Keterampilan Keahlian Menjual & \\
\hline 1 & Kemampuan yang bersangkutan untuk mendapatkan pesanan dari pelanggan & [7] \\
\hline 2 & $\begin{array}{l}\text { Kemampuan yang bersangkutan untuk melakukan presentasi penjualan } \\
\text { secara jelas dan konsisten }\end{array}$ & \\
\hline 3 & Kemampuan yang bersangkutan untuk melayani pelanggan & \\
\hline III & Keterampilan Pemasaran & \\
\hline 1 & $\begin{array}{l}\text { Kemampuan dalam memperoleh informasi terkini tentang perubahan } \\
\text { kebutuhan pelanggan }\end{array}$ & {$[10]$} \\
\hline 2 & $\begin{array}{l}\text { Yang bersangkutan memiliki banyak informasi mengenai persaingan yang } \\
\text { sangat baik }\end{array}$ & \\
\hline 3 & Yang bersangkutan memiliki banyak informasi mengenai tren industri & \\
\hline 4 & Berpengetahuan luas atas kejadian-kejadian penting di industri cat & \\
\hline IV & Pengetahuan Produk Perusahaan & \\
\hline 1 & $\begin{array}{l}\text { Keterampilan dan pengetahuan yang bersangkutan terhadap produk cat } \\
\text { Perusahaan }\end{array}$ & [7] \\
\hline 2 & $\begin{array}{l}\text { Keterampilan dan pengetahuan yang bersangkutan tentang kinerja pada } \\
\text { produk cat Perusahaan }\end{array}$ & \\
\hline 3 & $\begin{array}{l}\text { Kemampuan yang bersangkutan memahami spesifikasi umum dari produk cat } \\
\text { Perusahaan }\end{array}$ & \\
\hline 4 & $\begin{array}{l}\text { Keterampilan dan pengetahuan yang bersangkutan mengenai proses } \\
\text { pengiriman produk cat Perusahaan }\end{array}$ & \\
\hline 5 & $\begin{array}{l}\text { Keterampilan dan pengetahuan yang bersangkutan terkait fitur dan manfaat } \\
\text { produk cat Perusahaan }\end{array}$ & \\
\hline $\mathbf{V}$ & Pengetahuan Produk Pesaing & \\
\hline 1 & $\begin{array}{l}\text { Keterampilan dan pengetahuan yang bersangkutan terhadap produk cat } \\
\text { Pesaing }\end{array}$ & [7] \\
\hline 2 & $\begin{array}{l}\text { Keterampilan dan pengetahuan yang bersangkutan tentang kinerja pada } \\
\text { produk cat Pesaing }\end{array}$ & \\
\hline
\end{tabular}




\begin{tabular}{lll}
\hline No & \multicolumn{1}{c}{ Uraian } & Referensi \\
\hline 3 & $\begin{array}{l}\text { Kemampuan yang bersangkutan memahami spesifikasi umum dari produk cat } \\
\text { Pesaing }\end{array}$ & \\
4 & $\begin{array}{l}\text { Keterampilan dan pengetahuan yang bersangkutan mengenai proses } \\
\text { pengiriman produk cat Pesaing }\end{array}$ & \\
5 & $\begin{array}{l}\text { Keterampilan dan pengetahuan yang bersangkutan terkait fitur dan manfaat } \\
\text { produk cat Pesaing }\end{array}$ & \\
\hline VI & Kinerja Tenaga Penjual & [29] \\
1 & Kontribusi Omset Salesman terhadap Market Share Perusahaan \\
2 & Efektivitas Salesman dalam menghasilkan penjualan yang tinggi & \\
3 & Efektivitas Salesman dalam melampaui target dan sasaran penjualan tahunan & \\
\hline
\end{tabular}

\section{HASIL DAN PEMBAHASAN}

\subsection{Analisis Data}

Prosedur statistik dalam batas tertentu dapat memastikan validitas dan reliabilitas langkahlangkah analisis, dengan asumsi penilaian teoritis yang baik telah dipertimbangkan sebelumnya. Prosedur analisis data memungkinkan para peneliti untuk memastikan konsep yang pada awalnya dimodelkan dapat dibuktikan dengan analisis data.

Proses analisis data sampel dari penelitian ini menggunakan perangkat lunak SPSS Statistik edisi 26. Di bawah ini adalah hasil analisis data kuesioner.

\subsubsection{Analisis Deskriptif}

Kuesioner atau alat riset ditujukan kepada sales supervisor yang memberi tanggapan serta menilai tenaga penjual. Jumlah sales supervisor adalah
57 orang dengan pengalaman kerja di bidang penjualan 6-10 tahun (40,35\%) dan telah lama bekerja di perusahaan selama 2-5 tahun $(43,86 \%)$. Hal ini mengonfirmasi bahwa responden memiliki pengalaman yang cukup untuk menilai tenaga penjual. Mayoritas responden adalah pria $(94,74 \%)$ dengan usia terbanyak 25-35 tahun (59,65\%).

Total tenaga penjual yang dinilai sebanyak 268 orang, dengan pengalaman kerja di bidang penjualan terbanyak $2-5$ tahun $(54,48 \%)$ dan telah lama bekerja di perusahaan paling banyak 2-5 tahun $(61,19 \%)$. Mayoritas tim penjual berjenis kelamin pria (89.93\%) dan bersuku Jawa $(49,63 \%)$ serta kelompok usia $25-35$ tahun (75.75\%). Untuk pendidikan, sebagian besar berpendidikan SMA atau sederajat (72,01\%). Profil demografis responden ditunjukkan pada tabel 2 dan profil demografis tenaga penjual ditunjukkan pada tabel 3.

Tabel 2. Profil demografi responden

\begin{tabular}{llcc}
\hline No & \multicolumn{1}{c}{ Uraian } & Frekuensi & Presentasi (\%) \\
\hline I & Usia & & \\
1 & Di bawah 25 tahun & 1 & 1.75 \\
2 & 25-35 tahun & 34 & 59.65 \\
3 & $36-45$ tahun & 20 & 35.09 \\
4 & 46-55 tahun & 2 & 3.51 \\
& Total & $\mathbf{5 7}$ & $\mathbf{1 0 0 . 0 0}$ \\
\hline II & Jenis Kelamin & & \\
1 & Pria & 54 & 94.74 \\
2 & Wanita & 3 & 5.26 \\
& Total & $\mathbf{5 7}$ & $\mathbf{1 0 0 . 0 0}$ \\
\hline III & Suku & & \\
1 & Jawa & 26 & 45.61 \\
2 & Sunda & 5 & 8.77 \\
3 & Melayu & 2 & 3.51 \\
4 & Tionghoa & 10 & 17.54 \\
5 & Lainnya & 14 & 24.56 \\
& Total & $\mathbf{5 7}$ & $\mathbf{1 0 0 . 0 0}$ \\
\hline
\end{tabular}

IV Pendidikan




\begin{tabular}{llcc}
\hline No & \multicolumn{1}{c}{ Uraian } & Frekuensi & Presentasi (\%) \\
\hline 1 & SMA atau sederajat & 28 & 49.12 \\
2 & Diploma & 6 & 10.53 \\
3 & S-1 & 23 & 40.35 \\
4 & S-2 & 0 & 0.00 \\
3 & S-3 & 0 & 0.00 \\
& Total & $\mathbf{5 7}$ & $\mathbf{1 0 0 . 0 0}$ \\
\hline $\mathbf{V}$ & Jabatan Sales & & \\
1 & National sales manager & 0 & 0.00 \\
2 & Regional manager & 1 & 1.75 \\
3 & Sales manager & 3 & 5.26 \\
4 & Sales Supervisor & 53 & 92.98 \\
& Total & $\mathbf{5 7}$ & $\mathbf{1 0 0 . 0 0}$ \\
\hline VI & Pengalaman Tenaga Penjual & & \\
1 & Di bawah 1 tahun & 2 & 3.51 \\
2 & 2-5 tahun & 15 & 26.32 \\
3 & 6-10 tahun & 23 & 40.35 \\
4 & 11-15 tahun & 10 & 17.54 \\
5 & DI atas 15 tahun & 7 & 12.28 \\
& Total & $\mathbf{5 7}$ & $\mathbf{1 0 0 . 0 0}$ \\
\hline VI & Pengalaman Tenaga Penjual & & \\
1 & Di bawah 1 tahun & 0 & 0.00 \\
2 & 2-5 tahun & 25 & 43.86 \\
3 & 6-10 tahun & 16 & 28.07 \\
4 & 11-15 tahun & 9 & 15.79 \\
5 & DI atas 15 tahun & 7 & 12.28 \\
& Total & $\mathbf{5 7}$ & $\mathbf{1 0 0 . 0 0}$ \\
\hline
\end{tabular}

Tabel 3. Profil demografi tenaga penjual

\begin{tabular}{clcc}
\hline No & Uraian & Frekuensi & Presentasi (\%) \\
\hline I & Cabang & & \\
1 & Jawa & 176 & 65.67 \\
2 & Sumatera & 33 & 12.31 \\
3 & Kalimantan & 21 & 7.84 \\
4 & Sulawesi & 21 & 7.84 \\
5 & Bali - Nusa Tenggara & 17 & 6.34 \\
& Total & $\mathbf{2 6 8}$ & $\mathbf{1 0 0 . 0 0}$ \\
\hline II & Usia & & \\
1 & Di bawah 25 tahun & 39 & 14.55 \\
2 & 25-35 tahun & 203 & 75.75 \\
3 & 36-45 tahun & 26 & 9.70 \\
& Total & $\mathbf{2 6 8}$ & $\mathbf{1 0 0 . 0 0}$ \\
\hline III & Jenis Kelamin & & \\
1 & Pria & 241 & 89.93 \\
2 & Wanita & 27 & 10.07 \\
& Total & $\mathbf{2 6 8}$ & $\mathbf{1 0 0 . 0 0}$ \\
\hline IV & Suku & & 49.63 \\
1 & Jawa & 133 & 15.30 \\
2 & Sunda & 41 & 3.73 \\
3 & Melayu & 10 & 4.48 \\
4 & Tionghoa & 12 & 26.87 \\
5 & Lainnya & 72 & $\mathbf{1 0 0 . 0 0}$ \\
& Total & $\mathbf{2 6 8}$ & \\
\hline
\end{tabular}




\begin{tabular}{llcc}
\hline V & Pendidikan & & \\
1 & SMA atau sederajat & 193 & 72.01 \\
2 & Diploma & 24 & 8.96 \\
3 & S-1 & 51 & 19.03 \\
& Total & $\mathbf{2 6 8}$ & $\mathbf{1 0 0 . 0 0}$ \\
\hline VI & Pengalaman Tenaga Penjual & & \\
1 & Di bawah 1 tahun & 34 & 12.69 \\
2 & $2-5$ tahun & 146 & 54.48 \\
3 & 6-10 tahun & 79 & 29.48 \\
4 & 11-15 tahun & 6 & 2.24 \\
5 & DI atas 15 tahun & 3 & 1.12 \\
& Total & $\mathbf{2 6 8}$ & $\mathbf{1 0 0 . 0 0}$ \\
\hline VI & Pengalaman Tenaga Penjual & & \\
1 & Di bawah 1 tahun & 45 & 16.79 \\
2 & 2-5 tahun & 164 & 61.19 \\
3 & 6-10 tahun & 54 & 20.15 \\
4 & 11-15 tahun & 3 & 1.12 \\
5 & DI atas 15 tahun & 2 & 0.75 \\
& Total & $\mathbf{2 6 8}$ & $\mathbf{1 0 0 . 0 0}$ \\
\hline
\end{tabular}

\subsubsection{Analisis Faktor Eksplorasi}

Kelayakan suatu variabel dapat diketahui dengan menggunakan uji Kaiser-Meyer-Olkin (KMO) sementara keabsahan variabel dapat diuji dengan eigenvalues. Hasil analisis KMO semua variabel adalah $>0.5$ yang berarti bahwa teknik analisis pada penelitian ini layak untuk dilanjutkan seperti yang digambarkan pada tabel 4.

Langkah berikutnya setelah variabel divalidasi adalah menguji konsistensi internal. Jika pengukuran setiap variabel menunjukkan hasil yang konsisten dengan perhitungan Cronbach's Alpha di atas nilai cut-off 0.7 [37] maka dapat diartikan bahwa semua langkah analisis data dapat diandalkan. Berdasarkan tabel 4, semua variabel memiliki alpha lebih dari 0.7. Alpha terendah adalah variabel keterampilan penjualan (0.872) sementara alpha tertinggi adalah variabel pengetahuan produk perusahaan (0.956). Ini berarti bahwa kuesioner tersebut cocok untuk digunakan sebagai instrumen survei [38].

\subsubsection{Analisis Korelasi}

Pengujian analisis korelasi untuk menentukan tingkat keeratan hubungan antar variabel. Hubungan antar variabel dapat bersifat positif dan negatif [39], positif diartikan bahwa ada arah yang sama atau korelasi yang searah antar variabel yang diuji, sebaliknya menunjukkan arah yang berlawanan pada negatif. Analisis korelasi didapat dengan menggunakan uji Pearson Correlation, Tabel 5 menunjukkan hasil korelasi yang menggambarkan bahwa tingkat keeratan hubungan antar variabel cukup signifikan dan searah (positif).

Tabel 4. Analisis keabsahan dan keandalan data tiap variabel

\begin{tabular}{lccccc}
\hline Variabel & Kode & KMO MSA & Loadings & Eigenvalues & $\begin{array}{c}\text { Cronbach's } \\
\text { Alpha }\end{array}$ \\
\hline Keterampilan Interpersonal & A1 & 0.865 & 0.847 & 3.521 & 0.891 \\
& A2 & & 0.892 & & \\
& A3 & & 0.890 & & \\
& A4 & & 0.757 & & \\
& A5 & & 0.803 & & 0.872 \\
\hline Keterampilan Keahlian Menjual & A6 & 0.733 & 0.895 & 2.396 & \\
& A7 & & 0.874 & & \\
\hline Keterampilan Pemasaran & A8 & & 0.912 & & \\
& A9 & 0.712 & 0.826 & 3.014 & \\
& A10 & & 0.853 & & \\
& A11 & & 0.903 & &
\end{tabular}




\begin{tabular}{cccccc}
\hline Variabel & Kode & KMO MSA & Loadings & Eigenvalues & $\begin{array}{c}\text { Cronbach's } \\
\text { Alpha }\end{array}$ \\
\hline & A12 & & 0.888 & & \\
\hline Pengetahuan Produk Perusahaan & A13 & 0.887 & 0.924 & 4.269 & 0.956 \\
& A14 & & 0.947 & & \\
& A15 & & 0.934 & & \\
& A16 & & 0.870 & & \\
\hline A17 & & 0.944 & & 0.929 \\
& A18 & 0.836 & 0.918 & 3.902 & \\
& A19 & & 0.939 & & \\
\hline Kengetahuan Produk Pesaing & A20 & & 0.814 & & \\
& A21 & & 0.833 & & \\
& A22 & & 0.907 & & \\
\hline
\end{tabular}

Tabel 5. Analisis korelasi antar variabel

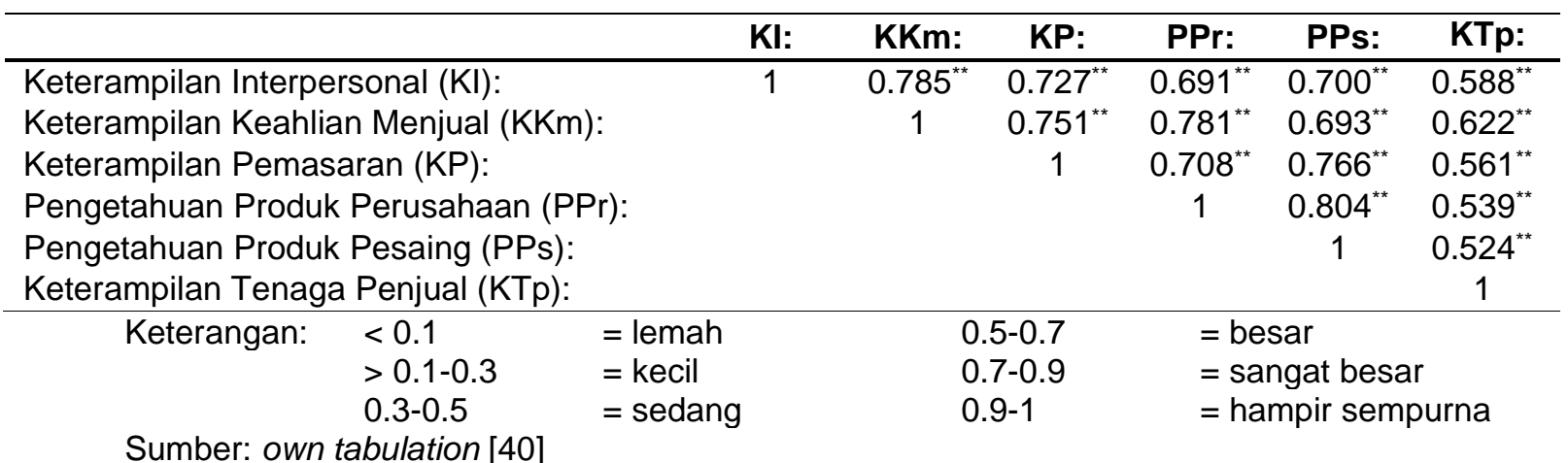

\subsubsection{Analisis Regresi}

Metode regresi linear digunakan untuk menguji hipotesis yang dikembangkan dalam penelitian ini. Ringkasan model pada hasil komputasi SPSS menunjukkan nilai koefisien determinasi $\left(R^{2}\right)$ yang berguna untuk memprediksi atau melihat seberapa besar kontribusi pengaruh yang diberikan variabel independen $(x)$ secara simultan (bersama-sama) terhadap variabel dependen (y).

Sebelum memaknai $\mathrm{R}^{2}$ maka perlu ada pemenuhan persyaratan yaitu penunjukkan hasil yang siginifikan pada hasil uji $\mathrm{F}$ dalam analisis regresi linear. Tabel 5 menunjukkan angka signifikansi (Sig.) sebesar $0.00001 \quad(p<0.05$ [36]) dan pembacaan hasil secara menyeluruh adalah bahwa variabel independen $(x)$ secara simultan memberikan pengaruh yang signifikan terhadap variabel dependen (y) dengan kontribusi pengaruh $\left(\mathrm{R}^{2}\right)$ sebesar $42.3 \%$, dalam pengertian yang lain adalah bahwa kontribusi pengaruh $\left(R^{2}\right)$ sebesar $57.7 \%$ dipengaruhi oleh variabel lain yang tidak terdapat dalam penelitian ini.

Standardized Coefficients (B) semua variabel menunjukkan nilai yang positif yang berarti variabel independen $(x)$ searah dengan variabel dependen (y). Besar signifikansi hipotesis dalam penelitian ini ditunjukkan dengan nilai significant (Sig.) setiap variabel dependen ( $\mathrm{x}$ ), tabel 5 menunjukkan bahwa hanya ada 2 (dua) variabel independen $(x)$ yang memenuhi $p<0.05$ yaitu variabel keterampilan interpersonal (0.021) dan keterampilan penjualan (0.001). 
Tabel 6. Analisis regresi

\begin{tabular}{lcccccc}
\hline \multicolumn{1}{c}{ Variabel Independen } & $\begin{array}{c}\text { Standardized } \\
\text { Coeeficients } \\
\mathbf{B}\end{array}$ & $\begin{array}{c}\text { Tolerance } \\
\text { Value } \\
\mathbf{t}\end{array}$ & Sig. & $\mathbf{F}$ & $\mathbf{R}^{\mathbf{2}}$ & $\begin{array}{c}\text { Adjusted } \\
\mathbf{R}^{\mathbf{2}}\end{array}$ \\
\hline Konstan & & 1.445 & 0.00001 & 38.487 & 0.423 & 0.412 \\
Keterampilan Interpersonal & 0.192 & 2.327 & 0.021 & & & \\
Keterampilan Keahlian Menjual & 0.326 & 3.487 & 0.001 & & & \\
Keterampilan Pemasaran & 0.117 & 1.385 & 0.167 & & & \\
Pengetahuan Produk Perusahaan & 0.206 & 0.277 & 0.782 & & & \\
Pengetahuan Produk Pesaing & 0.054 & 0.592 & 0.554 & & & \\
\hline
\end{tabular}

Variabel dependen: Kinerja tenaga penjualan, ${ }^{\star} p<0.05$

\subsubsection{Uji Hipotesis}

Hipotesis diuji berdasarkan hasil analisis regresi yang disajikan dalam Tabel 6 . Ringkasan hasil pengujian hipotesis disediakan pada Tabel 7 . Penelitian ini menemukan bahwa ada 2 hipotesis $(\mathrm{H} 1$ \& $\mathrm{H} 2)$ yang diterima. Pada $\mathrm{H} 1$ terdapat hubungan yang positif dan signifikan antara keterampilan interpersonal terhadap kinerja tenaga penjualan $\left(\beta=.192, \quad p<.021, \Delta \mathrm{R}^{2}=.423\right)$, dengan demikian uji hipotesis $\mathrm{H} 1$ ini konsisten dengan penelitian sebelumnya yang menunjukkan bahwa keterampilan interpersonal secara signifikan memprediksi kinerja tenaga penjualan [11]. Namun berbeda pada hipotesis H2, dimana pada penelitian ini $\mathrm{H} 2$ diterima karena terdapat hubungan yang positif dan signifikan antara keterampilan keahlian menjual terhadap kinerja tenaga penjualan $\left(\beta=.326, p<.001, \Delta \mathrm{R}^{2}=.423\right)$. Menariknya adalah pada hasil uji $\mathrm{H} 3, \mathrm{H} 4$ dan $\mathrm{H} 5$ menunjukkan nilai $\beta$ positif yang berarti variabel independen berhubungan positif terhadap variabel dependen namun tidak menunjukkan signifikansi yang kuat, nilai $p$-value masingmasing adalah $.167, .782 \& .554$ sehingga dengan demikian $\mathrm{H} 3, \mathrm{H} 4$ dan $\mathrm{H} 5$ ditolak.

Tabel 7. Ringkasan hasil uji hipotesis

\begin{tabular}{lcc}
\hline \multicolumn{1}{c}{ Hubungan } & Hipotesis & Hasil \\
\hline $\begin{array}{l}\text { Keterampilan } \\
\text { Interpersonal }\end{array}$ & $\mathrm{H} 1$ & Didukung \\
$\begin{array}{l}\text { Keterampilan } \\
\text { Keahlian } \\
\text { Menjual }\end{array}$ & $\mathrm{H} 2$ & Didukung \\
$\begin{array}{l}\text { Keterampilan } \\
\text { Pemasaran }\end{array}$ & $\mathrm{H} 3$ & Tidak didukung \\
$\begin{array}{l}\text { Pengetahuan } \\
\text { Produk }\end{array}$ & $\mathrm{H} 4$ & Tidak didukung \\
$\begin{array}{l}\text { Perusahaan } \\
\text { Pengetahuan }\end{array}$ & $\mathrm{H} 5$ & Tidak didukung \\
$\begin{array}{l}\text { Produk } \\
\text { Pesaing }\end{array}$ & & \\
\hline
\end{tabular}

Kertocahyono, dkk

\subsection{Pembahasan}

Berdasarkan pemaparan dan evaluasi yang merupakan produk penelitian terlihat bahwa ada korelasi positif yang signifikan antara 2 variabel yaitu keterampilan interpersonal dan keterampilan keahlian menjual terhadap kinerja tenaga penjual, sedangkan 3 variabel lainnya yaitu keterampilan pemasaran, pengetahuan produk perusahaan dan keterampilan produk pesaing memiliki hubungan positif namun tidak signifikan terhadap kinerja tenaga penjual. Hasil ini berbeda dengan hasil penelitian sebelumnya dari [11] yang menemukan bahwa hanya keterampilan interpersonal saja yang berpengaruh positif signifikan terhadap kinerja tenaga penjual. Hasil penelitian ini juga berbeda dengan penelitian [9] yang mengatakan bahwa pengetahuan produk perusahaan dan pengetahuan produk pesaing memiliki pengaruh positif terhadap kinerja tenaga penjual. Pada penelitian [9] jenis industri perusahaan yang diteliti adalah perusahaan mobil dan tenaga penjual menjual langsung ke konsumen akhir yang akan menggunakan mobil tersebut. Dalam kondisi ini pengetahuan produk perusahaan dan pesaing terkait spesifikasi mobil berperan penting terhadap keputusan pembelian konsumen akhir. Sedangkan dalam penelitian ini, tenaga penjual menjual kepada toko yang merupakan salah satu saluran distribusi. Pemilk toko juga memerlukan pengetahuan produk perusahaan dan pesaing tetapi dua dimensi tersebut tidak signifikan menentukan keputusan pembelian toko.

Penelitian ini menunjukkan hasil serupa dengan penelitian sebelumnya untuk variabel keterampilan interpersonal di mana menunjukkan hubungan positif dengan kinerja tenaga penjual. Keterampilan interpersonal mencerminkan kemampuan individu untuk berinteraksi dengan orang lain dan umumnya akan memupuk hubungan interpersonal yang positif [41]; [42]. [4] menyatakan bahwa keterampilan interpersonal tercermin dalam hal persuasi yang efektif, cara 
memberi penjelasan yang baik, dan mekanisme memengaruhi lainnya yang menunjukkan kemampuan untuk membujuk dan mengendalikan orang lain. Hasil ini menyiratkan bahwa kinerja tenaga penjual dapat ditingkatkan dengan mempekerjakan tenaga penjual dengan tingkat keterampilan interpersonal yang tinggi. Selanjutnya, dengan mempekerjakan tenaga penjual dengan tingkat keterampilan interpersonal yang lebih tinggi, akan lebih mungkin untuk mempertahankan dan membangun loyalitas pelanggan, meningkatkan pembelian berulang, dan lebih banyak mengembangkan hubungan jangka panjang dengan pelanggan mereka sesuai dengan [27] dan [43]

Dalam industri cat retail, peran pemilik toko masih sangat besar dalam melakukan pembelian barang. Kemampuan tim penjual untuk menjalin hubungan dan mendapatkan kepercayaan dari pemilik toko menjadi kunci keberhasilan penjualan. Di sini peran penting keterampilan interpersonal sangat dibutuhkan. Penelitian ini juga menemukan hubungan positif antara keterampilan keahlian menjual dan kinerja tenaga penjual. Ini berarti bahwa tingkat keahlian menjual yang tinggi berkorelasi dengan kinerja tinggi. Temuan ini mendukung pendapat bahwa manajemen dapat meningkatkan kinerja tenaga penjual dengan memiliki atau merekrut tenaga penjual dengan keterampilan keahlian menjual yang tinggi. Jadi, hal ini menyiratkan bahwa program-program seperti pelatihan dan pengembangan keterampilan menjual dan memiliki tenaga penjual dengan pengalaman kerja yang lebih lama menjadi salah satu cara untuk meningkatkan kinerja tenaga penjual.

Memiliki pemahaman dan wawasan mengenai pasar dapat mencerminkan kemampuan dan wawasan tenaga penjual mengenai situasi industri secara umum, seperti tingkat persaingan maupun kecenderungan dari pergerakan pasar. Latar belakang pengetahuan yang mendalam sangat penting bagi tenaga penjualan, mengingat pengetahuan tersebut memungkinkan tenaga penjualan dalam mengatasi lingkungan dan tantangan pasar yang lebih kompleks. Diharapkan bahwa tenaga penjual dengan keterampilan pemasaran tinggi akan menghasilkan kinerja yang baik [44]; [45]. Meskipun demikian, hasil dari penelitian ini tidak mendukung [10] yang menemukan bahwa keterampilan pemasaran memiliki hubungan yang signifikan dengan kinerja tenaga penjual. Temuan penelitian ini menyiratkan bahwa tenaga penjual tidak perlu memiliki pengetahuan tentang pasar yang mereka layani untuk mencapai target penjualan.
Sehubungan dengan alasan hubungan yang tidak signifikan antara keterampilan pemasaran dan kinerja tenaga penjual, beberapa hal yang mungkin menjadi penyebabnya adalah sifat industri, orientasi perusahaan dan struktur organisasi penjualannya. Cat yang merupakan produk industri lebih mengutamakan promosi penjualan melalui personal selling dibandingkan iklan di media elektronik. Kegiatan promosi lebih banyak dilakukan langsung ke saluran penjualan seperti toko-toko, supermarket bahan bangunan dan langsung ke pemakai akhir seperti kontraktor pengecatan dan tukang-tukang. Kondisi ini membuat orientasi perusahaan cenderung lebih banyak pada penjualan dibandingkan pemasaran. Pelatihan-pelatihan yang dilakukan lebih banyak untuk pengembangan keterampilan penjualan. Organisasi penjualan juga lebih banyak didominasi oleh tim penjualan.

Penelitian ini juga mengatakan bahwa tidak ada hubungan yang signifikan baik antara pengetahuan produk perusahaan dan kinerja tenaga penjual maupun pengetahuan produk pesaing terhadap kinerja tenaga penjual. Hasil ini konsisten dengan penelitian sebelumnya dari [11] dan [10] yang menyatakan tingkat keterampilan teknis tinggi yang dimiliki oleh tenaga penjual tidak selalu mengarah ke efek positif kinerja tenaga penjual. Hasil penelitian ini berbeda dengan [9] yang menemukan bahwa ada pengaruh positif pengetahuan produk perusahaan dan pengetahuan produk pesaing terhadap kinerja tenaga penjual. Tidak adanya hubungan yang signifikan antara pengetahuan produk dan kinerja tenaga penjual dapat dijelaskan dari tiga perspektif. Pertama, tenaga penjual yang diteliti adalah tenaga penjual untuk pasar retail, dimana produk-produk yang dijual pada pasar retail adalah produk standard yang umum ada di pasar seperti cat tembok, cat kayu, cat besi, dan lain-lain yang tidak memerlukan pengetahuan teknis untuk mengaplikasikannya. Kedua, sasaran penjualan untuk menghasilkan omset adalah pemilik toko yang relatif tidak terlalu fokus terhadap pengetahuan teknis dan lebih fokus terhadap manfaat yang mereka terima seperti tingkat keuntungan, kemudahan pengembalian produk dan tempo pembayaran. Ketiga, saat ini saluran informasi sudah sangat terbuka luas. Hal-hal teknis seperti pengetahuan produk dapat ditampilkan dalam bentuk video yang langsung bisa disebarluaskan melalui aplikasi whattsapp, facebook, instagram dan lain-lain. Hal ini menyebabkan tuntutan tenaga penjual harus memiliki pengetahuan produk menjadi berkurang. 
Dua dimensi yang signifikan terhadap kinerja penjualan adalah keterampilan interpersonal dan keterampilan keahlian menjual. Kedua keterampilan ini akan meningkat seiring dengan bertambahnya pengalaman seorang tenaga penjual. Dari profil demografi tenaga penjual tampak bahwa $87,31 \%$ tenaga penjual memiliki pengalaman kerja di bidang penjualan lebih dari 1 tahun dan $83,21 \%$ telah memiliki pengalaman kerja lebih dari 1 tahun.

Dimensi keterampilan pemasaran, pengetahuan produk perusahaan serta pengetahuan produk pesaing tidak signifikan berpengaruh terhadap kinerja penjualan. Ketiga keterampilan ini akan meningkat seiring dengan bertambahnya pengetahuan tenaga penjual terhadap ilmu pemasaran, pengetahuan produk perusahaan dan pengetahuan produk pesaing. Profil demografi seperti usia, jenis kelamin, suku, pendidikan, pengalaman di bidang penjualan dan pengalaman kerja tidak berkorelasi dengan ketiga variabel tersebut.

\section{KESIMPULAN}

Konteks penelitian ini telah ditetapkan untuk menguji dimensi keterampilan penjualan yaitu keterampilan interpersonal, keterampilan keahlian menjual, keterampilan pemasaran dan keterampilan teknis yang dijabarkan menjadi dua yaitu pengetahuan produk perusahaan serta pengetahuan produk pesaing. Berdasarkan pada beberapa tinjauan literatur, maka lima hipotesis berkaitan dengan hubungan dimensi keterampilan penjualan dan kinerja tenaga penjual diuji. Subyek atau responden dari penelitian ini adalah tenaga penjual di salah satu perusahaan cat Indonesia. Sebanyak 268 responden dari ukuran sampel 348 berpartisipasi dalam survei. Dari lima hipotesis yang diuji, dukungan hanya ditemukan untuk dua hipotesis yang menunjukkan bahwa ada hubungan yang signifikan antara keterampilan keahlian menjual dan kinerja tenaga penjual serta antara keterampilan interpersonal dan kinerja tenaga penjual.

Meskipun ada beberapa temuan yang berbeda dengan penelitian sebelumnya, hasil dari penelitian ini menunjukkan bahwa tenaga penjual memiliki keterampilan keahlian menjual dan keterampilan interpersonal dapat secara signifikan meningkatkan kinerja tenaga penjual. Dengan mengetahui pentingnya keterampilan keahlian menjual dan keterampilan interpersonal, perusahaan harus memberikan penekanan kepada peningkatan metode pelatihan dan pengembangan untuk meningkatkan keterampilan keahlian menjual dan keterampilan interpersonal tenaga penjual.

Beberapa keterbatasan penelitian ini akan memberikan arahan untuk perbaikan penelitian berikutnya. Pertama, penelitian ini terbatas pada tenaga penjual dalam satu perusahaan. Meskipun ini cocok untuk menguji kerangka kerja, penggunaan sampel dari satu perusahaan tertentu membatasi generalisasi hasil penelitian. Sebuah studi banding yang melibatkan sampel dari banyak perusahaan di industri yang sama akan berguna untuk menguji kerangka kerja sekaligus dapat memberikan generalisasi temuan yang lebih baik.

Kedua, dimensi keterampilan tenaga penjual dalam penelitian ini terbatas pada lima dimensi yaitu keterampilan interpersonal, keahlian menjual, pemasaran, pengetahuan produk perusahaan dan pengetahuan produk pesaing. Penelitian di masa depan harus menyelidiki kemungkinan menambahkan dimensi tambahan yang juga dapat memengaruhi kinerja tenaga penjual seperti motivasi, keterampilan persentasi, keterampilan manajemen umum serta manajemen keuangan.

Ketiga, pemilihan responden yang seluruhnya adalah sales supervisor memiliki beberapa keterbatasan. Idealnya, kelompok responden yang lebih beragam untuk mengevaluasi kinerja tenaga penjual. Selain itu, karena tenaga penjual lebih banyak berhubungan dengan pelanggan, disarankan penilaian tenaga penjual dilakukan oleh pelanggan. Pelanggan dapat menilai tenaga penjual dengan lebih baik pada aspek-aspek yang memengaruhi sikap pelanggan dan pembelian mereka.

Keempat, penelitian ini menggunakan pengukuran subyektif terhadap kinerja tenaga penjual berdasarkan kuesioner. Penelitian yang menggunakan pengukuran subyektif dan obyektif diharapkan akan memberikan pemahaman yang lebih baik terhadap hubungan antara variabel keterampilan dan kinerja tenaga penjual.

Penelitian ini dilakukan dalam kerangka bisnis perusahaan dan saluran distribusi (toko cat dan toko bahan bangunan), dimana yang diteliti adalah tenaga penjual perusahaan yang menjual ke saluran distribusi. Penelitian lanjutan dapat dilakukan dengan meneliti tenaga penjual pada perusahaan cat yang menjual langsung kepada konsumen akhir. 


\section{DAFTAR PUSTAKA}

[1] G. B. G. Indonesia, "Indonesia Paint \& Coating Industri," Global Business Guide Indonesia, 2017. http://www.gbgindonesia.com/en/property/ article/2017/overview_of_the_indonesian_ paint_industry_still_promising_despite_slo wdown_11774.php.

[2] M. H. Morris, D. L. Davis, J. W. Allen, R. A. Avila, and J. Chapman, "Assessing the Relationships Among Performance Measures, Managerial Practices, and Satisfaction When Evaluating the Salesforce: A Replication and Extension," J. Pers. Sell. Sales Manag., vol. 11, no. 3, pp. 25-35, 1991, doi: 10.1080/08853134.1991.10753876.

[3] G. A. Churchill, N. M. Ford, S. W. Hartley, and O. C. Walker, "The Determinants of Salesperson Performance: A MetaAnalysis," J. Mark. Res., vol. 22, no. 2, p. 103, 1985, doi: $10.2307 / 3151357$.

[4] G. A. Churchill, N. M. Ford, M. Johnson, and O. C. Walker, Sales Force Management, 6th ed. Singapore: McGrawHill Co, 2000.

[5] T. N. Ingram, R. W. LaForge, R. A. Avila, S. J. Charles, and M. R. Williams, Sales Management: Analysis and Decision Making, 5th ed. Ohio: Thomson SouthWestern, 2004.

[6] C. M. Futrell, Fundamental of Selling: Customer For Life Through Services, 9th ed. New York: McGraw-Hill Irwin, 2006.

[7] J. O. Rentz, C. D. Shepherd, A. Tashchian, P. A. Dabholkar, and R. T. Ladd, "A Measure of Selling Skill: Scale Development and Validation," J. Pers. Sell. Sales Manag., vol. 22, no. 1, pp. 13-21, 2002,

$10.1080 / 08853134.2002 .10754289$.

[8] S. Z. Ahmad, B. M. Sah, and P. J. Kitchen, "The Relationship Between Sales Skills and Salesperson Performance, and the Impact of Organizational Commitment as a Moderator: An Empirical Study in a Malaysian Telecommunications Company," Int. J. Econ. Manag., vol. 4, no. 2, pp. 181-211, 2010.
[9] V. Sangtani and F. Murshed, "Product Knowledge and Salesperson Performance: Rethinking the Role of Optimism," Mark. Intell. Plan., vol. 35, no. 6, pp. 724-739, 2017, doi: 10.1108/MIP11-2016-0199.

[10] M. Ahearne and N. Schillewaert, "The Effect of Information Technology on Salesperson Performance," 2000.

[11] M. S. Basir, S. Z. Ahmad, P. J. Kitchen, and U. Kingdom, "The Relationship Between Sales Skills and Salesperson Performance: An Empirical Study in the Malaysia Telecommunications Company," Relatsh. Between Sales Ski. Salesperson Perform. An Empir. Study Malaysia Telecommun. Co., vol. 3, no. 1, pp. 51-73, 2010.

[12] N. M. Ford, O. C. Walker, G. A. Churchill, and S. W. Hartley, "Selecting Successful Salespeople: A Meta-Analysis of Biographical and Psychological Selection Criteria in Review of Marketing 1988," Am. Mark. Assoc., 1988.

[13] L. B. Comer, T. Drollinger, N. Winter, P. Taylor, L. B. Comer, and T. Drollinger, "Linked References Are Available on Jstor For This Article: Active Empathetic Listening and Selling Success: A Conceptual Framework," vol. 19, no. 1, pp. 15-29, 1999.

[14] S. B. Castleberry and C. David Shepherd, "Effective Interpersonal Listening and Personal Selling," J. Pers. Sell. Sales Manag., vol. 13, no. 1, pp. 35-49, 1993, doi: 10.1080/08853134.1993.10753935.

[15] R. P. Ramsey and R. S. Sohi, "Listening To Your Customers: The Impact of Perceived Salesperson Listening Behavior on Relationship Outcomes," J. Acad. Mark. Sci., vol. 25, no. 2, pp. 127-137, 1997, doi: 10.1007/BF02894348.

[16] B. A. Weitz, "Effectiveness in Sales Interactions: A Contingency Framework," J. Mark., vol. 45, no. 1 , p. 85,1981 , doi: 10.2307/1251723.

[17] E. Babakus, D. W. Cravens, K. Grant, T. N. Ingram, and R. W. LaForge, "Investigating the Relationships Among Sales, 
Management Control, Sales Territory Design, Salesperson Performance, and Sales Organization Effectiveness," Int. J. Res. Mark., vol. 13, no. 4, pp. 345-363, 1996, doi: 10.1016/S0167-8116(96)00016$\mathrm{X}$.

[18] J. R. Goolsby, R. R. Lagace, and M. L. Boorom, "Psychological Adaptiveness and Sales Performance," J. Pers. Sell. Sales Manag., vol. 12, no. 2, pp. 52-66, 1992, doi: 10.1080/08853134.1992.10753907.

[19] D. W. Cravens, T. N. Ingram, R. W. LaForge, and C. E. Young, "BehaviorBased and Outcome-Based Salesforce Control Systems," J. Mark., vol. 57, no. 4, pp. 47-59, Oct. 1993, doi: 10.2307/1252218.

[20] C. P. Schuster and J. E. Danes, "Asking Questions: Some Characteristics of Successful Sales Encounters," J. Pers. Sell. Sales Manag., vol. 6, no. 1, 1986, doi: 10.1080/08853134.1986.10754410.

[21] T. F. Stafford, "Conscious and Unconscious Processing of Priming Cues in Selling Encounters," J. Pers. Sell. Sales Manag., vol. 16, no. 2, pp. 37-44, 1996, doi: 10.1080/08853134.1996.10754052.

[22] T. E. Whittler, "Eliciting Consumer Choice Heuristics: Sales Representives' Persuasion Strategies," J. Pers. Sell. Sales Manag., vol. 14, no. 4, pp. 42-53, 1994, doi: 10.1080/08853134.1994.10754002.

[23] K. C. Williams, R. L. Spiro, and L. M. Fine, "The Customer-Salesperson Dyad: An Interaction/ Communication Model and Review," J. Pers. Sell. Sales Manag., vol. 10, no. 3, 1990, doi: 10.1080/08853134.1990.10753832.

[24] K. C. Williams and R. L. Spiro, "Communication Style in the SalespersonCustomer Dyad," J. Mark. Res., vol. 22, no. 4, 1985, doi: $10.1177 / 002224378502200408$.

[25] S. Cho, "Influence of Consumer Age and Clothing Type of Salesperson on Consumer Satisfaction with Salesperson's Performance," Master Diss. Virginia Tech, 2001, doi: 10.1007/s11239-006-5570-0.
[26] T. W. Leigh and J. O. Summers, "An Initial Evaluation of Industrial Buyers' Impressions of Salespersons' Nonverbal Cues," J. Pers. Sell. Sales Manag., vol. 22, no. 1, pp. 41-53, 2002, doi: $10.1080 / 08853134.2002 .10754292$.

[27] G. L. Manning and R. Barry, Selling Today: Creating Customer Value, 9th ed. New Jersey: Pearson Education, 2004.

[28] S. Sengupta, R. E. Krapfel, and M. A. Pusateri, "An Empirical Investigation of Key Account Salesperson Effectiveness," J. Pers. Sell. Sales Manag., 2000, doi: 10.1080/08853134.2000.10754245.

[29] D. N. Behrman and W. D. Perreault, "Measuring The Performance of Industrial Salespersons," J. Bus. Res., vol. 10, no. 3, pp. 355-370, 1982, doi: 10.1016/01482963(82)90039-X.

[30] B. Artur and C. D. W., "The Effect Of Moderators on The Salesperson Behavior Performance and Salesperson Outcome Performance and Sales Organization Effectiveness Relationships," Eur. J. Mark., vol. 36, no. 11/12, pp. 1367-1388, Jan. 2002, doi: 10.1108/03090560210445227.

[31] J. C. Prabhu, R. K. Chandy, and M. E. Ellis, "The Impact of Acquisitions on Innovation: Poison Pill, Placebo, or Tonic?," J. Mark., vol. 69 , no. 1 , pp. 114-130, 2005, doi: 10.1509/jmkg.69.1.114.55514.

[32] K. Zheng, C. B. Li, K. Z. Zhou, and C. B. Li, "How Knowledge Affects Radical Innovation: Knowledge Base, Market Knowledge Acquisition, and Internal Knowledge Sharing Stable URL: https://www.jstor.org/stable/23261319

Research Notes and Commentaries How Knowledge Affects Radical Innovation: Acquisi," Strateg. Manag. J., vol. 33, no. 9, pp. 1090-1102, 2012, doi: 10.1002/smj.I959.

[33] C. Baumgarth and M. Schmidt, "How Strong Is The Business-To-Business Brand in The Workforce? An EmpiricallyTested Model of 'Internal Brand Equity' in a Business-To-Business Setting," Ind. Mark. Manag., vol. 39, no. 8, pp. 12501260, 2010, doi: 
10.1016/j.indmarman.2010.02.022.

[34] L. M. De Luca and K. Atuahene-Gima, "Market Knowledge Dimensions and Cross-Functional Collaboration: Examining the Different Routes To Product Innovation Performance," J. Mark., vol. 71, no. 1, 2007, doi: 10.1509/jmkg.71.1.95.

[35] J. C. Darian, L. A. Tucci, and A. R. Wiman, "Perceived Salesperson Service Attributes and Retail Patronage Intentions," Int. J. Retail Distrib. Manag., vol. 29, no. 5, pp. 205-213, May 2001, doi: 10.1108/09590550110390986.

[36] R. Cavana, B. Delahaye, and U. Sekaran, Applied Business Research: Qualitative and Quantitative Methode, 3rd ed. Australia: John Wiley \& Sons, 2001.

[37] J. C. Nunnally and I. H. Bernstein, Psychometric Theory, 3rd ed. McGrawHill, 1994.

[38] J. Hair, W. Black, B. Babin, R. Anderson, and R. Tatham, Multivariate Data Analysis, 6th ed. Upper Saddle River: Pearson Prentice Hall, 2006.

[39] L. Egghe and L. Leydesdorff, "The Relation Between Pearson's Correlation Coefficient $r$ and Salton's Cosine Measure," J. Am. Soc. Inf. Sci. Technol. 60(5), 2009, doi: 10.1002/asi.21009.

[40] S. F. Padlee, C. Y. Thaw, and S. N. Atikah Zulkiffli, "The Relationship Between Service Quality, Customer Satisfaction and Behavioural Intentions in the Hospitality Industry," Tour. Hosp. Manag., vol. 25, no. 1, pp. 121-139, 2019, doi: 10.20867/thm.25.1.9.

[41] J. L. Gibson, J. M. Ivancevich, and D. J. James, Organizations: Behavior Structure Process, 9th ed. United States: McGrawHill Irwin, 1997.

[42] W. A. Hochwarter, C. Kiewitz, M. J. Gundlach, and J. Stoner, "The Impact of Vocational and Social Efficacy on Job Performance and Career Satisfaction," J. Leadersh. Organ. Stud., vol. 10, no. 3, 2004, doi: 10.1177/107179190401000303.

[43] B. A. Weitz, S. B. Castleberry, and J. F. Tanner Jr, Selling: Building the Partnership. United States: McGraw-Hill
Irwin, 1998.

[44] T. W. Leigh and P. F. McGraw, "Mapping the Procedural Knowledge of Industrial Sales Personnel: A Script-Theoretic Investigation," J. Mark., vol. 53, no. 1, p. 16, 1989, doi: 10.2307/1251522.

[45] H. Sujan, M. Sujan, and J. R. Bettman, "Knowledge Structure Differences between More Effective and Less Effective Salespeople," J. Mark. Res., vol. 25, no. 1, 1988, doi: 10.2307/3172927.

\section{Biografi Penulis}

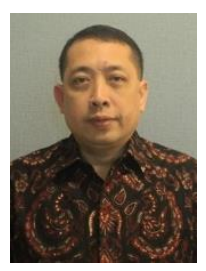

Aria Eddy Kertocahyono, S.E, adalah konsultan investment banking yang memperoleh gelar Sarjana Ekonomi Jurusan Akuntansi Fakultas Ekonomi Universitas Pancasila pada tahun 2004. Penulis juga telah memperoleh sertifikasi Certified Public Accountant dari Institut Akuntan Publik Indonesia (IAPI) dan Wakil Manajer Investasi dari The Indonesia Capital Market Institute (TICMI). Saat ini penulis sedang mengikuti program Magister Manajemen Strategic Management di Prasetiya Mulya Business School angkatan 55 .

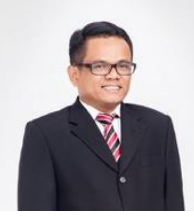

Haryanto Ginting, S.E Ak., saat ini aktif bekerja pada salah satu perusahaan tambang terbesar di Indonesia sebagai Internal Auditor. Sebelumnya penulis juga pernah aktif dalam organisasi nirlaba dan perusahaan akuntan publik. Penulis memperoleh gelar Sarjana Ekonomi Jurusan Ekonomi Fakultas Ekonomi Universitas Indonesia pada tahun 1998. Saat ini penulis sedang mengikuti program Magister Manajemen Strategic Management di Prasetiya Mulya Business School angkatan 55 .

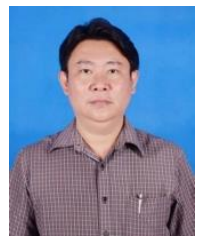

Julius Kurata, S.T., saat ini bekerja di sebuah perusahaan cat nasional di bidang sales \& marketing. Penulis memperoleh gelar Sarjana Teknik Jurusan Teknik Mesin Institut Teknologi Sepuluh Nopember Surabaya pada tahun 1997 dan Sarjana Ekonomi Jurusan Manajemen Universitas Katolik Widya Mandala Surabaya pada tahun 1998. 


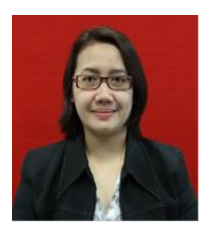

Risnawati Dermauli, S.E Ak., secara aktif bekerja di salah satu perusahaan minyak dan gas bumi nasional dalam bidang keuangan selama 18 tahun. Di periode 18 tahun ini, penulis memiliki pengalaman selama kurang lebih 10 tahun di bidang audit atas bagi hasil yang dikoordinasikan kepada Auditor Pemerintah seperti SKK Migas dan BPKP, serta Auditor Negara BPK. Penulis memperoleh gelar Sarjana Ekonomi Jurusan Akuntansi Fakultas Ekonomi Universitas Indonesia pada tahun 1998. Saat ini penulis sedang mengikuti program Magister Manajemen Strategic Management di Prasetiya Mulya Business School angkatan 55.

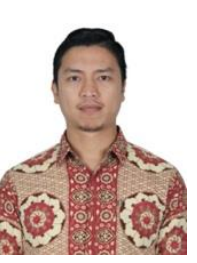

Sony Chandra Sihaloho, S.T., saat ini aktif bekerja di salah satu perusahaan konstruksi nasional sejak tahun 2008. Penulis memiliki pengalaman selama kurang lebih 12 tahun di bidang konstruksi pada proyek-proyek di Indonesia. Penulis memperoleh gelar Sarjana Teknik Jurusan Teknik Elektro Fakultas Teknik Universitas Sumatera Utara pada tahun 2007. Saat ini penulis sedang mengikuti program Magister Manajemen Strategic Management di Prasetiya Mulya Business School angkatan 55. 